\title{
Penerapan Konselor Sebaya dalam Mengoptimalkan Fungsi Layanan Bimbingan Konseling di Sekolah
}

\author{
Andi Ahmad Ridha \\ Fakultas Psikologi, Universitas Airlangga \\ email: a.ahmad.ridha-2015@psikologi.unair.ac.id
}

\begin{abstract}
Abstrak
\section{Artikel INFO}

Diterima:10 Januari 2019

Direvisi :14 februari 2019

Disetujui: 28 Maret 2019

DOI:

http://dx.doi.org/10.24014/ jp.v14i2.6549

Pada dasarnya pemberian layanan konseling adalah tugas guru bimbingan dan konseling (Guru BK) di sekolah. Namun, layanan yang diberikan kurang efektif karena terbatas jumlah guru BK dan terbatasnya kesempatan untuk memberikan layanan kepada seluruh siswa. Penerapan konselor sebaya disinyalir dapat mengatasi kelemahan yang dimiliki sistem layanan konseling di sekolah. Penelitian ini bertujuan untuk menerapkan konselor sebaya sebagai salah satu strategi mengatasi lemahnya fungsi BK di sekolah. Penelitian ini dilakukan di salah satu SMK di Surabaya.Penelitian ini menggunakan metode kualitatif dengan tipe penelitian tindakan kelas. Penelitian ini dilakukan dalam 2 siklus ( 3 sesi pada masing-masing siklus). Subjek penelitian berjumlah 4 orang siswa yang direkomendasikan oleh wali kelas. Hasil yang diperoleh dalam penelitian ini adalah penerapan konselor sebaya dapat meningkatkan fungsi layanan BK di sekolah. Hal tersebut dapat diuraikan sebagai berikut: 1) siswa-siswa di sekolah menunjukkan kesediaannya secara sukarela untuk mendatangi ruang BK dan berkonsultasi dengan konselor sebaya pada jam istirahat. Hasil pengamatan menunjukkan adanya lonjakan siswa yang berkonsultasi di jam-jam istirahat; 2) Penerapan konselor sebaya dipengaruhi oleh beberapa hal, yaitu jenis permasalahan yang dialami dan keterbukaan siswa dalam menyampaikan permasalahan; dan 3) Penerapan konselor sebaya sangat membantu guru BK dalam menjangkau seluruh siswa yang memerlukan bantuan penyesuaian di sekolah.
\end{abstract}

Kata kunci: Layanan Bimbingan Konseling, Guru BK, Konselor Sebaya

\section{Application of Peer Counselors in Optimizing the Functions of Guidance Counseling Services in Schools}

\begin{abstract}
Basically the provision of counseling services is the task of the guidance and counseling teacher (GC Teacher) at the school. However, the services provided are less effective because of the limited number of GC teachers and the limited opportunities to provide services to all students. The application of peer counselors was allegedly able to overcome the weaknesses of the counseling service system in schools. This study aims to apply peer counselors as a strategy to overcome the weak function of GC in schools. This research was conducted in one of the Vocational Schools in Surabaya. This study uses qualitative methods with the type of classroom action research. This research was conducted in 2 cycles ( 3 sessions in each cycle). The research subjects were 4 students recommended by the homeroom teacher. The results obtained in this study are the application of peer counselors can improve GC service functions in schools. This can be explained as follows: 1) students in the school show their willingness to voluntarily go to the GC room and consult with peer counselors at rest time. The results of the observations indicate that there is a surge in students who consult during breaks; 2) The application of peer counselors is influenced by several things, namely the types of problems experienced and the openness of students in conveying problems; and 3) The application of peer counselors is very helpful for GC teachers in reaching all students who need adjustment assistance at school.
\end{abstract}

Keywords: Counseling Guidance Service, Guidance and Counseling Teacher, Peer Counselor 


\section{Pendahuluan}

SMK Negeri X di Surabaya merupakan sekolah kejuruan yang bergerak di bidang pariwisata. Berdasarkan data kasus yang dimiliki guru Bimbingan Konseling (BK), diketahui bahwa siswa-siswa memiliki masalah yang sangat kompleks, seperti masalah prestasi belajar siswa yang rendah, siswa yang sering bolos sekolah, siswa yang memiliki masalah keluarga hingga berdampak pada penurunan prestasi belajar, hingga kasus tawuran, pencurian, free sex, dan penggunaan narkoba.

Data kasus tersebut menunjukkan bahwa siswa membutuhkan layanan bimbingan konseling (BK). Layanan BK merupakan layanan bantuan untuk peserta didik baik individu/ kelompok agar mandiri dan berkembang secara optimal dalam hubungan pribadi, sosial, karir, melalui berbagai jenis layanan dan kegiatan pendukung atas dasar norma-norma yang berlaku (Tulus, 2016). Menurut Permendikbud No.111 Thn 2014 Pasal 3, layanan BK memiliki tujuan membantu konseli mencapai perkembangan optimal dan kemandirian secara utuh dalam aspek pribadi, belajar, sosial, dan karir.

Permasalahan siswa yang cukup banyak, tidak didukung oleh memadainya layanan BK di sekolah. Hal ini terlihat dari jumlah guru BK yangsaat ini berjumlah 7 orang. Guru yang berkualifikasi S1 psikologi pendidikan dan bimbingan konseling serta berhak memberikan layanan BK hanya terdapat 3 orang. Sementara 4 orang lainnya bukan merupakan lulusan $\mathrm{S} 1$ psikologi pendidikan dan bimbingan konseling.

Sementara itu, jumlah keseluruhan siswa di SMKN X Surabaya adalah \pm 1.600 siswa. Berdasarkan Permendikbud No.111 Thn 2014 Pasal 1 ayat 4, Guru BK adalah pendidik yang berkualifikasi akademik minimal
Sarjana Pendidikan (S-1) dalam bidang BK dan memiliki kompetensi di bidang BK.

Meskipun dibantu oleh empat guru lainnya, namun layanan guru BK kurang efektif karena tidak semua siswa mendapatkan layanan BK. Siswa yang mendapatkan layanan BK hanyalah siswa yang telah teridentifikasi mengalami permasalahan. Dari siswa yang bermasalah, hanya beberapa yang mengikuti layanan $\mathrm{BK}$, sementara siswa lainnya yang telah teridentifikasi mengalami permasalahan, justru menghindarilayanan BK. Selebihnya, guru BK hanya memaksimalkan pada jam pelajaran BK untuk mengajarkan materi-materi terkait dengan potensi yang harus dikembangkan oleh siswa agar bisa menjalankan fungsinya sebagai siswa yang mandiri di sekolah.

Penyusunan prosedur layanan BK di sekolah seharusnya dibuat berdasarkan pedoman umum dalam Permendikbud No.111 Thn 2014. Adapun dalam memberikan layanan BK, terdapat pedoman yang seharusnya dilakukan oleh guru BK yaitu: melakukan identifikasi dan pengumpulan data, menganalisis dan mendiagnosis masalah, melakukan prognosis, memberikan perlakuan secara sistematis dan kontinu, mengevaluasi dan menindaklanjuti.

Dari hasil observasi peneliti terhadap siswa-siswa yang sedang menjalani proses konseling di ruang BK, menunjukkan bahwa beberapa siswa cukup tertutup dan tidak mau mengemukakan masalah yang sesungguhnya sehingga seringkali proses konseling diakhiri dengan melakukan pemanggilan terhadap orangtua dan diberikan surat pernyataan untuk memperbaiki perilakunya.

Adanya siswa yang tidak mau mengemukakan masalahnya terhadap guru BK, dapat disebabkan oleh tidak adanya privasi dan ketenangan yang dirasakan oleh 
siswa dalam ruang BK. Dengan melihat rasio antara guru $\mathrm{BK}$ dan jumlah siswa dan berbagai permasalahan yang ada di SMKN X Surabaya, dapat dikatakan bahwa proses pelaksanaan konseling dinilai kurang efektif karena layanan BK yang diterapkan di sekolah belum berfungsi secara maksimal, manfaat layanan BK belum dirasakan oleh seluruh siswa, dan bahkan siswa enggan mendatangi ruang $\mathrm{BK}$ dan menghindari layanan BK yang akan diberikan.

Salah satu strategi yang dapat dilakukan untuk memaksimalkan fungsi layanan BK yaitu dengan menerapkan peran siswa sebagai konselor sebaya di sekolah. Suwarjo (2008) mengemukakan bahwa siswa pada SMP, SMA, dan SMK sesuai dengan usia perkembangannya berada pada masa remaja. Pada masa ini, ketertarikan dan komitmen serta ikatan terhadap teman sebaya menjadi sangat kuat. Hal ini antara lain karena remaja merasa bahwa orang dewasa tidak dapat memahami mereka. Keadaan ini sering menjadikan remaja sebagai suatu kelompok yang eksklusif karena hanya sesama merekalah dapat saling memahami.

Hasil penelitian yang dilakukan Salmiati, Hasbahuddin, dan Bakhtiar (2018) menunjukkan bahwa pelatihan konselor sebaya menjadi salah satu strategi dalam memecahkan permasalahan siswa di sekolah. Selain itu, dengan adanya konselor sebaya, dapat mengantisipasi munculnya kenakalan remaja. Konseling sebaya dapat menjadi nilai tambah dalam bidang pengetahuan dan keterampilan untuk siswa sehingga dapat membantu mengoptimalkan kinerja guru BK.

Sebagian besar siswa lebih sering membicarakan masalah-masalah serius mereka dengan teman sebaya, dibandingkan denganorangtuadangurupembimbing. Siswasiswa dalam menceritakan permasalahan yang serius seperti hubungan seksual dan kehamilan di luar nikah, dan keinginan untuk melakukan aboris, ia ceritakan kepada temantemannya, bukan kepada orangtua maupun guru. Kalaupun terdapat beberapa siswa yang akhirnya menceritakan kehamilan atau hubungan seksual mereka kepada orang tua atau guru pembimbing, biasanya karena sudah terpaksa (pembicaraan dan upaya pemecahan masalah bersama teman sebaya mengalami jalan buntu) (Suwarjo, 2008).

$$
\text { Hamachek (Widodo, }
$$

mengemukakan bahwa dalam perkembangannya, individu tidak dapat terlepas dari hubungannya dengan kelompok sosial lainnya, misalnya kelompok teman sebaya. Lingkungan/kelompok ini akan ikut menentukan bagaimana individu itu berkembang. Tidak menutup kemungkinan adanya sifat kesebayaan ini, justru individu akan memperoleh keuntungan tertentu, antara lain bahwasannya kelompok teman sebaya dapat dijadikan sebagai pengganti keluarga, dapat berfungsi menstabilkan pengaruh selama masa transisi, sebagai sumber memperoleh harga diri, perlindungan dari paksaan orang dewasa.

Bramer (Widodo, 2012) mengemukakan bahwa banyak orang cenderung lebih suka mengemukakan persoalan (sharing atau curhat) kepada teman-teman dekatnya/teman sebaya daripada kepada guru atau orang tua. Hal ini disebabkan karena sesama remaja tahu persis lika-liku masalah itu dan lebih spontan dalam mengadakan kontak.

Glosoff dan Koprowicz (Fathiyah \& Harahap, 2008) mengemukakan bahwa konseling merupakan proses yang dilakukan oleh profesional terlatih dalam hubungan saling percaya terhadap individu yang membutuhkan bantuan. Konseling sebaya dinilai cukup efektif karena diberikan oleh 
teman sebayanya sendiri. Pada remaja ada kecenderungan untuk memiliki personal fable yaitu keyakinan bahwa hanya dia yang mengalami pengalaman unik, bukan orang dewasa lain.

Hasil penelitian yang dilakukan Sarmin (2017) menunjukkan bahwa pemberdayaan siswa sebagai konselor sebaya di sekolah dapat mengurangi pengaruh negatif lingkungan. Hasil penelitian yang dilakukanAini (2016) menunjukkan bahwa resiliensi siswa dapat ditingkatkan melalui layanan konseling sebaya. Oleh karena itu, penguatan melalui konseling sebaya dipandang cukup bermakna untuk dilakukan. Berdasarkan pemaparan di atas, maka dapat dirumuskan suatu pertanyaan penelitian yaitu bagaimanakah mekanisme dan penerapan konselor sebaya dalam mengoptimalkan fungsi layanan BK di SMK X Surabaya?

\section{Metode}

Penelitian ini menggunakan metode penelitian kualitatif dengan tipe penelitian tindakan kelas (PTK). Penelitian ini berupaya mengatasi keterbatasan fungsi layanan BK di sekolah dengan menerapkan peran siswa sebagai konselor sebaya di sekolah. Penelitian yang dilakukan melalui tahapan: perencanaan, pelaksanaan, observasi, dan refleksi.

PTK dilakukan dalam 2 siklusdan terdapat 3 sesi dalam setiap siklus pelaksanaan penelitian. Refleksi dilakukan di akhir siklus sebagai bahan evaluasi bagi subjek untuk meningkatkan kinerja pada siklus 2. Penelitian direncanakan dilakukan dalam waktu 2 siklus dalam waktu 2 minggu (3-14 September 2018) dan 2 jam per sesi dalam 1 siklus. Berikut disajikan rincian waktu dan durasi pelaksanaan penelitian tindak kelas:
Tabel 1.Pelaksanaan PTK untuk Subjek AN dan DM

\begin{tabular}{|c|c|c|c|}
\hline & $\begin{array}{l}\text { Sesi I } \\
\text { Senin }\end{array}$ & $\begin{array}{l}\text { Sesi II } \\
\text { Selasa }\end{array}$ & $\begin{array}{c}\text { Sesi III } \\
\text { Rabu }\end{array}$ \\
\hline $\begin{array}{l}\text { Siklus } \\
\mathrm{I}(\text { Minggu I) }\end{array}$ & $\begin{array}{c}08.00- \\
10.00\end{array}$ & $\begin{array}{l}10.00- \\
12.00\end{array}$ & $\begin{array}{l}13.00- \\
15.00\end{array}$ \\
\hline $\begin{array}{l}\text { Siklus II } \\
\text { (Minggu II) }\end{array}$ & $\begin{array}{c}13.00- \\
15.00\end{array}$ & $\begin{array}{l}10.00- \\
12.00\end{array}$ & $\begin{array}{c}08.00- \\
10.00\end{array}$ \\
\hline
\end{tabular}

Tabel 2. Pelaksanaan PTK untuk Subjek AG dan FB

\begin{tabular}{cccc}
\hline & $\begin{array}{c}\text { Sesi I } \\
\text { Rabu }\end{array}$ & $\begin{array}{c}\text { Sesi II } \\
\text { Kamis }\end{array}$ & $\begin{array}{c}\text { Sesi III } \\
\text { Jumat }\end{array}$ \\
\hline $\begin{array}{c}\text { Siklus I } \\
\text { (Minggu I) }\end{array}$ & $\begin{array}{c}08.00- \\
10.00\end{array}$ & $10.00-$ & $13.00-$ \\
& & & 15.00 \\
Siklus II & $10.00-$ & $10.00-$ & $08.00-$ \\
(Minggu II) & 12.00 & 12.00 & 10.00 \\
\hline
\end{tabular}

\section{Subjek Penelitian}

Subjek dalam penelitian ini terdiri atas 4 orang siswa kelas $\mathrm{XI}$ yang berprestasi dan direkomendasikan oleh wali kelas/ guru BK, dan telah mengikuti pelatihan konselor sebaya yang dilaksanakan oleh Dinas Pendidikan Kota Surabaya.

\section{Pengukuran}

Penelitian ini menggunakan pedoman observasi berdasarkan layanan bimbingan dan konseling yang tepat berdasarkan Permendikbud No.111 Thn 2014.Di setiap sesi dilakukan observasi untuk mendapatkan data terkait kemajuan yang dialami pada setiap siklus.

Penilaian hasil observasi dilakukan dengan menilai indikator-indikator yang dipenuhi (keterampilan konseling, supervisi oleh guru BK, antusias dari konseli, dan pelaksanaan konseling yang sistematis) oleh subjek penelitian. Penilaian berkisar dari 1-7 yang mengindikasikan perilaku dari "kurang baik - baik". 


\section{Analisis Data}

Data dianalisis secara deskriptif dengan membandingkan hasil observasi PTK pada siklus 1 dan siklus 2, masing-masing siklus terdiri atas 3 sesi penerapan konselor sebaya.

\section{Hasil}

Gambaran Layanan Konseling di SMK $X$ Surabaya

Berdasarkan hasil wawancara peneliti terhadap koordinator guru BK, diperoleh informasi bahwa, guru BK di sekolah belum mempunyai alur mengenai pemberian layanan BK kepadasiswa-siswa disekolah. Guruhanya memberikan layanan BK sesuai dengan jadwal mengajar di kelas dan memberikan layanan di ruang BK hanya bersifat insidental. Ketika terdapat aduan dari wali kelas, guru BK baru bertindak dengan melakukan pemanggilan kepada siswa beserta orangtuanya.

Sementara itu, siswa-siswa terpilih yang sebelumnya telah mengikuti program pelatihan konselor sebaya yang diadakan pihak Dinas Pendidikan kota Surabaya, tidak ditindaklanjuti oleh pihak sekolah. Berdasarkan hasil analisis peneliti, maka ditawarkan perubahan alurl mekanisme layanan BK di sekolah dengan memanfaatkan peran konselor sebaya sehingga layanan BK dapat berfungsi sebagaimana mestinya.

Berdasarkan aturan Permendikbud No.111 Thn 2014 mengenai pedoman pemberian layanan BK, maka dapat disusun alur/ mekanisme penerapan konselor sebaya yang disesuaikan dengan karakteristik layanan BK yang dimiliki SMK X Surabaya. Berikut disajikan alur/ mekanisme penerapan konselor sebaya yang ditawarkan:

membantu mengoptimalkan fungsi BK dengan alur penerapan sebagai berikut:

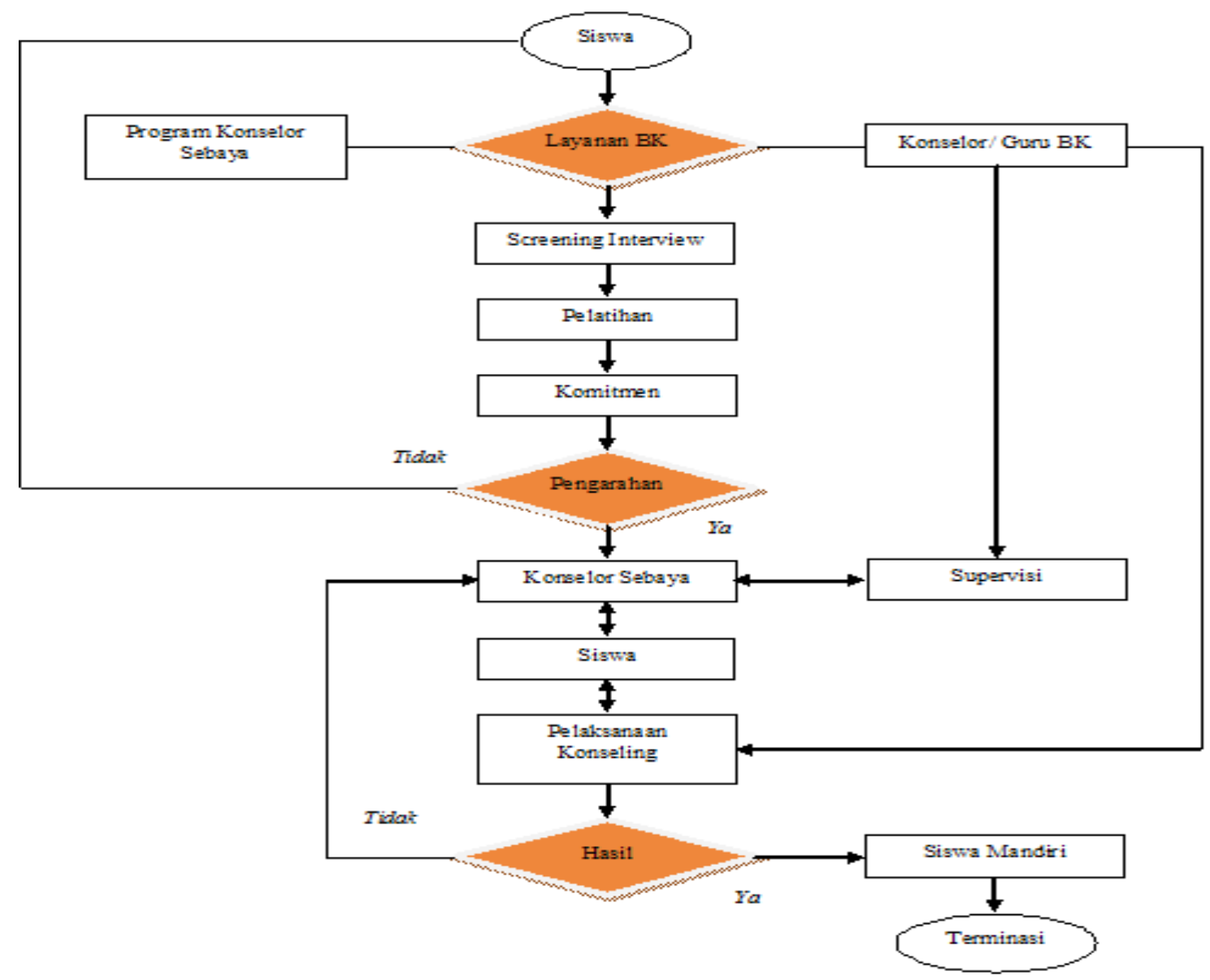

Alur pererapan konselor sebaya dalam layanan BK

Gambar 1. Mekanisme Penerapan Konselor Sebaya di Sekolah 
Alur/ mekanisme penerapan konselor sebaya yang ditawarkan disusun berdasarkan aturan Permendikbud No.111 Thn 2014 mengenai pedoman pemberian layanan BK, yaitu: guru melakukan identifikasi dan pengumpulan data, menganalisis dan mendiagnosis masalah, melakukan prognosis, memberikan perlakuan secara sistematis dan kontinu, mengevaluasi dan menindaklanjuti.

Selain itu, alur/ mekanise penerapan konselor sebaya juga disesuaikan dengan tahapan prosedur penerapan konselor sebaya yang dimiliki Osisek (1982) bahwa bahwa dalam merekrut konselor sebaya dilakukan melalui: 1) mengikuti screening interview; 2) menyelesaikan program pelatihan; dan 3) memiliki komitmen selama setahun sebagai konselor sebaya,

Layanan BK di SMKX Surabaya memiliki rasio perbandingan guru $\mathrm{BK}$ dan siswa sekolah yang tidak imbang yaitu $7: \pm 1600$. Selain itu, fungsi BK juga kurang efektif karena mayoritas siswa secara sadar enggan mendatangi ruang BK untuk mendapatkan layanan BK dan siswa-siswa yang memiliki masalah pun enggan mengemukakan masalahnya kepada guru BK/ konselor.Oleh karena itu, peneliti membuatkan sistem yang dapat membantu guru BK menjalankan fungsinya dalam memberikan layanan BK.

Pihak sekolah pada dasarnya telah memiliki program pelatihan konselor sebaya yang diberikan oleh Dinas Pendidikan Kota Surabaya selama 1 hari kepada siswa-siswa yang direkomendasikan oleh pihak sekolah. Dalam memaksimalkan fungsi layanan BK, maka pihak sekolah dapat mengaktifkan peran konselor sebaya di sekolah. Guru BK merekrut siswa-siswa yang dianggap kompeten dan memiliki prestasi memuaskan sebagai calon konselor sebaya. Hal ini dapat dilakukan dengan menyebarkan informasi penerimaan konselor sebaya melalui wali kelas untuk disampaikan kepada siswa-siswa yang berminat menjadi konselor sebaya.

Hasil rekrutmen awal menjadi bahan bagi guru BK untuk melakukan screening interview. Screening interview dilakukan melalui beberapa tahapan yaitu: dengan menanyakan keinginannya untuk bergabung sebagai konselor sebaya, menanyakan harapan siswa, berapa lama ia dapat berkontribusi sebagai konselor sebaya, menanyakan apakah ia mengerti tuntutan yang ditujukan kepadanya sebagai konselor sebaya, dapatkah ia meluangkan waktu tambahan sebagai konselor sebaya, dan apakah ia pernah memiliki pengalaman sebelumnya mengikuti pelatihan atau pengalaman dalam melakukan konseling.

Dari hasil screening interview dapat diperoleh siswa yang berkualitas dan siswa tersebut diwajibkan mengikuti pelatihan konseling sebaya. Guru BK dapat menjadwalkan screening interview mendekati pelaksanaan program pelatihan konselor sebaya yang dilaksanakan oleh Dinas Pendidikan Kota Surabaya sehingga siswa dapat mengikuti program tersebut segera setelah dilakukan screening interview.

Setelah mengikuti program pelatihan konselor sebaya oleh Dinas Pendidikan Kota Surabaya. Pihak sekolah dan guru BK menindaklanjutihasil pelatihantersebutdengan memperdalam dasar-dasar keterampilan yang dibutuhkan sebagai konselor sebaya dalam jangka waktu tertentu.

Setelah siswa mengikuti serangkaian pelatihan, guru BK meminta komitmen siswa untuk menjadi konselor sebaya selama setahun.Jika siswa tidak mampu memberikan komitmen, siswa dinyatakan gugur dan diharapkan dapat mengaplikasikan ilmunya kepada teman-temannya secara sukarela. Jika siswa mampu menyatakan komitmennya 
untuk menjadi konselor sebaya, siswa dilantik sebagai konselor sebaya, diberikan supervisi, pendalaman materi konseling dan prosedur pelaksanaan konseling, mengaturjadwal piket, dan kewenangan untuk membantu kasuskasus yang dialami oleh teman-temannya.

Dalam proses pelaksanaan konseling, siswa (klien) berinteraksi dengan guru BK melalui konselor sebaya, dan siswa (klien) berinteraksi secara langsung dengan guru BK atas rujukan dari konselor sebaya.Jika dalam pelaksanaan konseling, siswa (klien) belum menunjukkan perubahan, maka layanan konseling tetap dilanjutkan bersama konselor sebaya dengan adanya supervisi dari guru BK dan konselor sebaya dapat merujuk langsung kepada guru BK untuk menangani permasalahan siswa (klien).Jika dalam pelaksanaan konseling, siswa (klien) menunjukkan perubahan yang positif, siswa menjadi siswa yang mandiri dan terbuka akan pengalaman sehingga dapat dilakukan terminasi.

Berikut disajikan perbandingan hasil observasi subjek penelitian pada siklus I dan siklus II pada gambar 2-5.

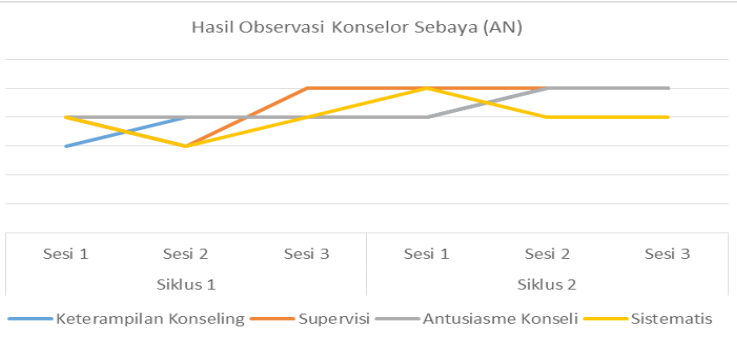

Gambar 2.Hasil Observasi Konselor Sebaya (AN)

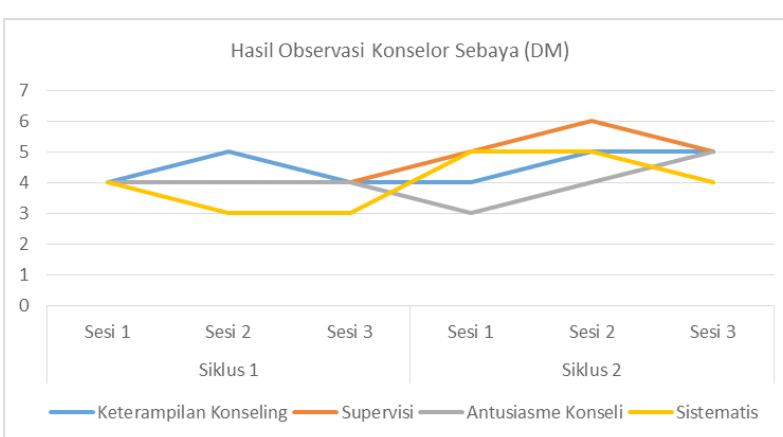

Gambar 3.Hasil Observasi Konselor Sebaya (DM)

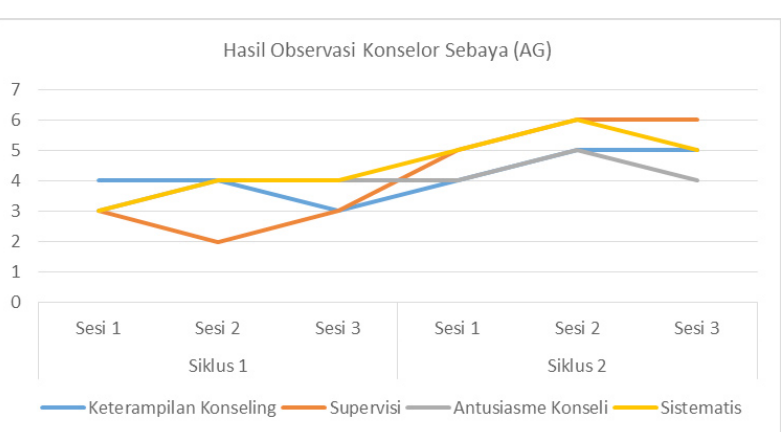

Gambar 4.Hasil Observasi Konselor Sebaya (AG)

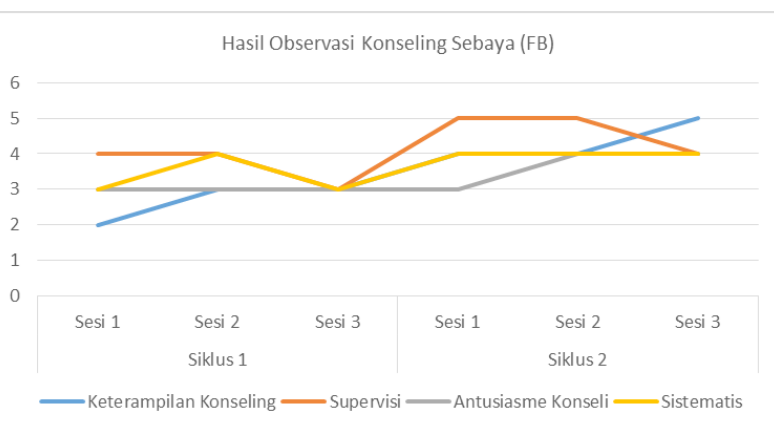

Gambar 5. Hasil Observasi Konselor Sebaya (FB)

Pada hasil penelitian yang ditampilkan dalam bentuk grafik di atas, menunjukkan bahwa terjadi perubahan perilaku ke arah yang lebih baik selama penerapan konselor sebaya yang terlihat pada siklus I dan siklus II. Siklus II menunjukkan peningkatan perilaku setelah diberikan refleksi atas penerapan konselor sebaya pada siklus I. Adapun keterampilan dasar konseling yang diobservasi yaitu attending, genuineness, asertif, bertanya, merangkum, konfrontasi, dan pemecahan masalah.

Darihasil observasi terlihatbahwa siswasiswa di sekolah menunjukkan kesediaannya secara sukarela untuk mendatangi ruang BK dan berkonsultasi dengan konselor sebaya padajam istirahat. Adanyalonjakan siswayang berkonsultasi pada jam istirahat. Penerapan konselor sebaya dipengaruhi oleh beberapa hal, yaitu jenis permasalahan yang dialami dan keterbukaan siswa dalam menyampaikan permasalahan. Penerapan konselor sebaya 
sangat membantu guru BK dalam menjangkau seluruh siswa yang memerlukan bantuan penyesuaian di sekolah.

Hasil observasi juga menunjukkan adanya variasi pemberian supervisi dari guru BK, antusiasme konseli, dan pelaksanaan konseling yang sistematis. Adanya variasi yang terjadi menunjukkan bahwa terdapat individual difference terkait kemampuan memerankan sosok sebagai konselor sebaya. Dari hasil observasi ditunjukkan bahwa adanya perbedaan pengalaman menangani masalah, kemampuan komunikasi, pribadi yang luwes, keterbukaan konseli, dan peran guru BK dalam memberikan supervisi secara berkelanjutanturutmemengaruhi keberhasilan siswa memerankan sosok sebagai konselor sebaya.

\section{Pembahasan}

Hasil penelitian ini menunjukkan bahwa konselor sebaya dapat menangani permasalahan yang tergolong ringan dan sedang, tergantung dari seberapa besar keterbukaan siswa yang menjadi konseli terhadap siswa yang menjadi konselor sebaya. Dari perbandingan antara siklus I dan II terlihat kemajuan yang dialami siswa dalam menerapkan keterampilan konseling. Kemampuan sebagai konselor sebaya tidak bisa diperoleh hanya dari pelatihan sehari dua hari melainkan berkelanjutan dan disertai dengan supervisi dari guru BK agar siswa semakin terampil dalam berperan sebagai konselor sebaya sehingga pada akhirnya peran siswa sebagai konselor sebaya dapat membantu kinerja guru BK dalam mengoptimalkan fungsi layanan BK di sekolah.

Hasil penelitian ini mendukung penelitian sebelumnya yang dilakukan Suranata (2013) bahwa konselor sebaya membutuhkan penguasaan keterampilan komunikasi atau wawancara konseling dan penguasaan prosedur dalam menjalankan konseling. Corey (2013) mengemukakan bahwa dalam menempati posisi sebagai konselor, tidak dapat dicapai secara instan, perlu upaya dan latihan secara terus-menerus mengembangkan sikap dan keterampilan sebagai konselor.

Hasil penelitian Erhamwilda (2011) menunjukkan bahwa kompetensi interpersonal siswa SMK dapat ditingkatkan melalui penerapan pemodelan konselor sebaya.Hal ini didukung oleh Gladding (2015) yang mengemukakan bahwa untuk mengembangkan sikap sebagai konselor yang genuine diperlukan banyak pengalaman dan latihan dalam merasakan empati kepada permasalahan orang lain. Hasil penelitian Shohib, Firmanto, Kusuma, dan Martasari (2016) menunjukkan bahwa konselor sebaya dapat membantu menangani permasalahanpermasalahan remaja yang kurang dapat dipahami oleh orang dewasa. Konselor sebaya membutuhkan karakter yang kuat seperti empati, menolong, proaktif, mendengarkan konseli, dan membantu mencari solusi. Hasil penelitian yang dilakukan Wardani dan Trisnani (2015) menunjukkan bahwa konseling sebaya efektif dalam meningkatkan perilaku prososial siswa di sekolah.

Hasil penelitian yang dilakukan Fathiyah dan Harahap (2008) menunjukkan bahwa terjadi peningkatan efikasi diri pada remaja SMA setelah melakukan sesi konseling bersama konselor sebaya. Hasil penelitian yang dilakukan Rohayati (2011) menunjukkan bahwa melalui program konselor teman sebaya dapat meningkatkan kepercayaan diri siswa. Endang (2008) mengemukakan bahwa pada dasarnya konseling teman sebaya merupakan wadah bagi para siswa belajar 
dan membantu teman-temannya.

Suranata (2013) menambahkan bahwa adanya keeratan, keterbukaan, perasaan senasib dapat menjadi peluang bagi konselor sebaya sebagai upaya memfasilitasi remaja memecahkan permasalahannya. George dan Cristiani (Latipun, 2015) mengemukakan bahwa terdapat enam karakteristik hubungan konseling yaitu: afeksi, intensitas, pertumbuhan dan perubahan, privasi, dorongan, dan kejujuran. Ketakutan remaja terhadap hal-hal yang sifatnya privasi yang sungkan dibicarakan dengan orang dewasa, dapat dihindari melalui penerapan konselor sebaya.

Osisek (1982) menyatakan bahwa untuk individu yang mengalami permasalahan sedang dan berat, tentunya harus mendapatkan penanganan dari seorang ahli. Sementara untuk individu yang mengalami permasalahan ringan dan situasional, dapat menghubungi konselor sebaya yang telah mendapatkan pelatihan dan supervisi dari ahli untuk mendapatkan penanganan yang efektif.

Osisek (1982) menambahkan bahwa dalam merekrut konselor sebaya dilakukan melalui: 1) mengikuti screening interview; 2) menyelesaikan program pelatihan; dan 3) memiliki komitmen selama setahun sebagai konselor sebaya. Hal tersebut sesuai dengan kondisi yang ada di SMK X Surabaya, karena pada dasarnya dari Dinas Pendidikan kota Surabaya sudah memberikan pelatihan konselor sebaya terhadap beberapa siswa berprestasi yang direkomendasikan pihak sekolah. Namun dari pihak sekolah tidak ada upaya untuk menindaklanjuti program tersebut.

Dengan melihat kenyataan yang ada, agar fungsi BK di SMKN X Surabaya dapat berjalan sebagaimana mestinya, maka pihak sekolah dapat merekrut siswa-siswa untuk menjadi konselor sebaya yang mampu membantu pihak BK memberikan layanan konseling secara merata kepada seluruh siswa dan menjadi alternatif solusi terhadap rasio guru BK dan jumlah siswa yang tidak imbang sehingga BK mampu menjalankan fungsinya sebagai bagian yang integral dalam pendidikan.

\section{Kesimpulan}

Penerapan konselor sebaya di sekolah menunjukkan perubahan yang positif dan membantu kinerja guru dalam memberikan layanan BK kepada siswa-siswa sekolah yang memiliki permasalahan penyesuaian di sekolah. Pelaksanaan konselor sebaya sebaiknya dilakukan secara kontinu dan diberi supervisi untuk meningkatkan kualitas siswa sebagai konselor sebaya. Pihak SMK X Surabaya diharapkan agar menerapkan mekanisme konselor sebaya di sekolah untuk mengoptimalkan pemberian layanan konseling sekolah. Penelitian ini memiliki implikasi dalam memperbaiki sistem layanan BK di sekolah dan memberikan kerangka/ mekanisme penerapan konselor sebaya di sekolah.

\section{Daftar Pustaka}

Aini, N. (2016). Efektivitas layanan konseling sebaya dalam meningkatkan resiliensi peserta didik kelas XII SMA Negeri 12 Bandar Lampung Tahun Ajaran 2016/2017.Skripsi. Fakultas Tarbiyah dan Keguruan: IAIN Raden Intan Lampung.

Corey, G. (2013). Teori dan praktek: Konseling \& psikoterapi. Cetakan ke-7. Bandung: Refika Aditama.

Endang, B. (2008). Konseling teman sebaya pada remaja di era globalisasi. FKIP: Universitas Tanjung Pura.

Erhamwilda. (2011). Peningkatan kompetensi interpersonal siswa SMK melalui Model Konseling Sebaya.Mimbar, XXVII(2): 173-182. 
Fathiyah, K. N., \& Harahap, F. (2008). Konseling sebaya untuk meningkatkan efikasi diri remaja terhadap perilaku berisiko.Artikel Penelitian. Yogyakarta: Fakultas IImu Pendidikan Universitas Negeri Yogyakarta.

Gladding, S. T. (2015). Konseling: Profesi yang menyeluruh. Cetakan ke-2.Edisi ke-6. Jakarta: Indeks.

Latipun.(2015). Psikologi konseling. Cetakan ke-9.Edisi ke-4. Malang: UMM Press.

Osisek, P. J. (1982). Peer counseling: Overview. (http://enil.eu/wp-content, diakses tanggal 25 November 2016).

Peraturan Menteri Pendidikan Dan Kebudayaan Republik Indonesia Nomor 111 Tahun 2014 Tentang Bimbingan Dan Konseling Pada Pendidikan Dasar Dan Pendidikan Menengah.

Rohayati, I. (2011). Program bimbingan teman sebaya untuk meningkatkan percaya diri siswa.Artikel Penelitian. Pascasarjana Universitas Pendidikan Indonesia.

Salmiati, Hasbahuddin, Bakhtiar, M.I. (2018). Pelatihan konselor sebaya sebagai strategi pemecahan masalah siswa.Matappa: Jurnal Pengabdian Masyarakat, 1(1): 36-41.

Sarmin. (2017). Konselor sebaya: Pemberdayaan teman sebaya dalam sekolah guna menanggulangi pengaruh negatif lingkungan. Brilliant: Jurnal Riset \& Konseptual, 2(1): 102112.

Shohib, M., Firmanto, A., Kusuma, W.A., Martasari, G.I. (2016). Pendamping -an kelompok konselor sebaya di Kota Batu. Jurnal Dedikasi, Vol. 13: 34-38.

Suranata, K. (2013). Pengembangan model tutor bimbingan konseling sebaya (peer counseling) untuk mengatasi masalah mahasiswa Fakultas IImu Pendidikan Undiksha.Jurnal Pendidikan Indonesia, 2(2): 255-263.

Suwarjo.(2008). Konseling teman sebaya (peer counseling) untuk mengembangkan resiliensi remaja. Semloknas Bimbingan dan Konseling. Jurusan Psikologi Pendidikan dan Bimbingan. Fakultas IImu Pendidikan. Universitas Pendidikan Indonesia.

Tulus, M. (2016).Bimbingan dan konseling. (https://mintotulus.wordpress.com/, diakses tanggal 6 Desember 2016).
Wardani, S.Y., \& Trisnani, R.P.(2015).Konseling sebaya untuk meningkatkan perilaku prososial siswa.Psikopedagogia, 4(2) 87-92.

Widodo, B. (2012). Konseling sebaya (Peer counseling). Madiun: FKIP Universitas Katolik Widya Mandala Madiun. 